\title{
Genetic diversity and selection gain in the physic nut (Jatropha curcas)
}

\author{
B.P. Brasileiro ${ }^{1}$, S.A. Silva ${ }^{2}$, D.R. Souza ${ }^{2}$, P.A. Santos ${ }^{2}$, R.S. Oliveira ${ }^{3}$ and \\ D.H. Lyra $^{4}$
}

${ }^{1}$ Departamento de Estatística, Universidade Federal de Viçosa, Viçosa, MG, Brasil

${ }^{2}$ Centro de Ciências Agrárias, Ambientais e Biológicas, Universidade Federal do Recôncavo da Bahia, Cruz das Almas, BA, Brasil ${ }^{3}$ Departamento de Ciências Biológicas, Universidade Estadual de Feira de Santana, Feira de Santana, BA, Brasil ${ }^{4}$ Departamento de Ciências Biológicas, Universidade Federal de Lavras, Lavras, MG, Brasil

Corresponding author: B.P. Brasileiro

E-mail: brunobiogene@hotmail.com

Genet. Mol. Res. 12 (3): 2341-2350 (2013)

Received March 29, 2012

Accepted August 11, 2012

Published January 4, 2013

DOI http://dx.doi.org/10.4238/2013.January.4.12

\begin{abstract}
The use of efficient breeding methods depends on knowledge of genetic control of traits to be improved. We estimated genetic parameters, selection gain, and genetic diversity in physic nut half-sib families, in order to provide information for breeding programs of this important biofuel species. The progeny test included 20 halfsib families in 4 blocks and 10 plants per plot. The mean progeny heritability values were: $50 \%$ for number of bunches, $47 \%$ for number of fruits, $35 \%$ for number of seeds, $6 \%$ for stem diameter, $26 \%$ for number of primary branches, $14 \%$ for number of secondary branches, $66 \%$ for plant height, and $25 \%$ for survival of the plants, demonstrating good potential for early selection in plant height, number of branches, and number of fruits per plant. In the analysis of genetic diversity, genotypes were divided into 4 groups. Genotypes 18, 19, 20, and 8 clustered together and presented the highest means for the vegetative
\end{abstract}


characters and production. Lower means were observed in the 17 , 12,13 , and 9 genotypes from the same group. We detected genetic variability in this population, with high heritability estimates and accuracy, demonstrating the possibility of obtaining genetic gains for vegetative characters and production at 24 months after planting.

Key words: Jatropha curcas; Selective accuracy; Ward-MLM; Genetic diversity

\section{INTRODUCTION}

The physic nut (Jatropha curcas L.) has been an alternative to the biodiesel program because of its high productivity and hardness, coupled with the quality of the oil extracted from its seeds (Openshaw, 2000), which contain 30-35\% oil that can be converted into goodquality biodiesel by transesterification (Foidl et al., 1996).

It is only during these last 30 years that studies on the agronomic species were initiated, since it is a plant that has not yet been domesticated (Fairless, 2007; Achten et al., 2008). Little is known about the physiology of the species, and its agronomic aspects should be further investigated (Achten et al., 2010).

Recently, different breeding programs for $J$. curcas have been implemented in Brazil, with the completion of initial assessments in the juvenile phase in half-sib families (Abreu et al., 2009; Juhász et al., 2010; Laviola et al., 2010; Freitas et al., 2011). These programs have been differentiated primarily with respect to the number of genotypes, plot size, and number of replication-used factors that affect estimates of genetic parameters and the prediction of selection gains.

The use of efficient methods of improvement depends fundamentally on the knowledge regarding the genetic control of the traits to be improved, such as the number of genes that govern a trait, actions and gene effects, heritability, repeatability, and the correlation between traits (Hallauer, 2007).

Like the evaluation, the characterization of the germplasm collection has a strategic application in the evaluation of genetic resources, in addition to providing basic data that are needed for breeding programs (Mohammadi and Prasanna, 2003).

Advances in computer technology, numerical taxonomy, and multivariate statistical analysis contributed to the conservation of genetic resources and formation of core collections (Ortiz et al., 2008) and allowed analysis of genetic diversity and identification of possible duplicates, besides providing parameters for the choice of parents that enable a more heterotic effect in the progeny and increasing the chances of obtaining transgressive genotypes in segregating generations.

The best method of numerical classification is the one that defines the most compact and well-separated groups, i.e., with minimum variation within the groups and maximum variation between groups (Crossa and Franco, 2004).

Franco et al. (1998) proposed the Ward modified location model (MLM) procedure as a replacement to the location model procedure proposed by Lawrence and Krzanowski (1996). This method also allows us to define the optimal number of groups and calculate a highly accurate measure of the groups by using all the information available about the accesses, whether they are quantitative or qualitative variables (Crossa and Franco, 2004). 
The aim of this study was to estimate genetic parameters, selection gain, and genetic diversity in half-sib progeny of the physic nut to promote breeding programs for the species.

\section{MATERIAL AND METHODS}

\section{Plant material and assessments}

Twenty half-sib progeny of the physic nut were used in the assessment, with 17 families obtained from the experimental station of Empresa Baiana de Desenvolvimento Agrícola (EBDA) located in Alagoinhas, BA, Brazil, and 3 families from the EBDA in Irará, BA, Brazil. The experiment was initiated in May 2008, in an area of 0.86 hectares in Cruz das Almas, BA, Brazil.

The experiment was conducted in a randomized block design with 20 treatments, 4 replicates, and 10 plants per plot, leading to a total of 800 plants.

The characteristics evaluated at 24 months after planting were the following: number of bunches (NB), number of fruits (NF), number of seeds (NS), stem diameter (SD), number of primary branches $(\mathrm{PB})$, number of secondary branches $(\mathrm{SB})$, plant height $(\mathrm{PH})$, and survival of the plants (PS).

\section{Statistical analysis}

Data were analyzed using the mixed model equation via restricted maximum likelihood and best linear unbiased predictor (BLUP) presented by Resende (2002) by using the following statistical model:

$$
y=X b+Z a+W c+e
$$

where $y, b, a, c$, and $e$ are data vectors, block effects (fixed), additive genetic effects (random), plot effects (random), and errors (random), respectively, and $X, Z$, and $W$ are incidence matrices for $b, a$, and $c$, respectively.

The estimates of genetic parameters were performed using the SELEGEN-REML/ BLUP software (Resende, 2007). Analyses of genetic correlations, multicollinearity, and path analysis were performed with the R software (R Development Core Team, 2012). Genetic diversity was examined using the Ward-MLM method, and the ideal number of groups was defined according to the criteria pseudo-F and pseudo- $\mathrm{t}^{2}$, together with the likelihood profile associated with the likelihood ratio test, by using SAS version 9.1.3 (SAS Institute Inc., 2007).

\section{RESULTS AND DISCUSSION}

\section{Genetic parameters}

The results of the genetic parameter estimates for the traits assessed 2 years after planting are presented in Table 1.

The traits, NB and PH had values of selective accuracy higher than 0.70 , and the variable NF showed an accuracy of 0.69 (Table 1). This parameter refers to the correlation between predicted values and true breeding values. 
Table 1. Genetic parameters estimated in Jatropha curcas progeny.

\begin{tabular}{|c|c|c|c|c|c|c|c|c|}
\hline Parameters & NB & $\mathrm{NF}$ & NS & PB & SB & $\mathrm{SD}(\mathrm{cm})$ & $\mathrm{PH}(\mathrm{cm})$ & PS \\
\hline $\mathrm{Va}$ & 0.25 & 3.08 & 9.36 & 0.06 & 0.42 & 0.10 & 271.71 & 0.003 \\
\hline $\mathrm{Ve}$ & 1.20 & 19.14 & 102.92 & 1.28 & 11.08 & 11.82 & 140.13 & 0.081 \\
\hline $\mathrm{Vf}$ & 1.56 & 23.44 & 118.22 & 1.37 & 12.87 & 12.15 & 511.63 & 0.086 \\
\hline $\mathrm{h}^{2}{ }_{\mathrm{a}}$ & 0.16 & 0.13 & 0.07 & 0.04 & 0.03 & 0.008 & 0.53 & 0.03 \\
\hline $\mathrm{h}^{\mathrm{i}^{\mathrm{a}}}$ & 0.50 & 0.47 & 0.35 & 0.26 & 0.14 & 0.06 & 0.66 & 0.25 \\
\hline Acuracy & 0.71 & 0.69 & 0.49 & 0.51 & 0.38 & 0.26 & 0.81 & 0.50 \\
\hline $\mathrm{CV}_{\mathrm{gi}}$ & 117.79 & 114.19 & 90.48 & 7.38 & 8.92 & 5.04 & 17.01 & 6.28 \\
\hline $\mathrm{CV}_{\mathrm{e}}^{\mathrm{gi}}$ & 116.34 & 119.17 & 121.70 & 12.15 & 21.62 & 18.72 & 11.95 & 10.78 \\
\hline $\mathrm{CV}_{\mathrm{r}}^{\mathrm{e}}$ & 0.50 & 0.47 & 0.37 & 0.30 & 0.20 & 0.13 & 0.71 & 0.29 \\
\hline Mean & 0.42 & 1.53 & 3.38 & 3.37 & 7.31 & 6.35 & 96.86 & 0.90 \\
\hline
\end{tabular}

$\mathrm{Va}=$ additive genetic variance; $\mathrm{Ve}=$ residual variance among plots; $\mathrm{Vf}=$ phenotypic variance; $\mathrm{h}_{\mathrm{a}}^{2}=$ individual narrow sense heritability; $\mathrm{h}_{\mathrm{mp}}^{2}=$ average progeny heritability; $\mathrm{CV}_{\mathrm{gi}}=$ coefficient of individual genetic variability; $\mathrm{CV}_{\mathrm{e}}=$ coefficient of environmental variation; $\mathrm{CV}_{\mathrm{r}}=$ coefficient of relative variation; $\mathrm{NB}=$ number of bunches; $\mathrm{NF}=$ number of fruits; $\mathrm{NS}=$ number of seeds; $\mathrm{PB}=$ number of primary branches; $\mathrm{SB}=$ number of secondary branches; $\mathrm{SD}=$ stem diameter; $\mathrm{PH}=$ plant height; $\mathrm{PS}=$ plant survival.

Higher the accuracy, greater will be the confidence in the evaluation of the predicted value of individuals and selection gains. Accuracy values higher than 0.70 are sufficient to provide an accurate inference about the genetic value of progenies. Moreover, the experimental evaluation of quality must be inferred on the basis of accuracy because of the ease of interpretation (Resende, 2002).

Overall, the heritability on individual sense was of low magnitude, ranging from 3 to $53 \%$ (Table 1). However, individual selection by the BLUP method also considers the information from relatives, a fact that provides a higher selective accuracy. Moreover, low heritability in the narrow sense is expected for quantitative traits (Resende, 2002).

The values of heritability for progeny average were $50 \%$ for NB, $47 \%$ for NF, $35 \%$ for NS, $26 \%$ for PB, $14 \%$ for SB, $6 \%$ for SD, $66 \%$ for PH, and $25 \%$ for PS (Table 1), which show good prospects for early selection in relation to $\mathrm{PH}, \mathrm{NB}$, and NF per plant.

With the selection of the 10 best plants for the traits NB, NF, and $\mathrm{PH}$, the predicted selection gain was $46.47,32.90$, and $20.32 \%$, respectively, demonstrating the possibility of high selection gains in the first production. However, the use of repeated measures may provide greater safety in the selection of the best genotypes.

The coefficients of individual genetic variation showed significant values for all traits, with emphasis on the production of variables and PH (Table 1). The coefficient of individual genetic variability is a relevant parameter in studies of quantitative genetics because it allows inferences about the magnitude of variability in populations and in different traits because it is expressed as a percentage of the average existing genetic variation (Resende, 2002).

The genetic parameters obtained for the vegetative traits were similar to those obtained by Ginwal et al. (2005), Rao et al. (2008), Abreu et al. (2009), Juhász et al. (2010), Laviola et al. (2010), and Freitas et al. (2011). However, Abreu et al. (2009) and Juhász et al. (2010) obtained higher values of accuracy, probably because of the large number of replications used since selective accuracy can be enhanced through an increased number of replications (Resende, 2002).

For the PH trait, the values of heritability $(0.66)$ and selective accuracy $(0.81)$ were significant and close to the results obtained by Abreu et al. (2009), Juhász et al. (2010), and Laviola et al. (2010). These authors suggested that vegetative traits should be evaluated and the correlation with production traits should be studied. 


\section{Genetic correlations and path analysis}

The fast and efficient utilization of available genetic variability is essential, and knowledge about the correlations between the traits is one of the ways to save time and reduce effort because it helps in the choosing appropriate selection procedures (Falconer and Mackay, 1996).

In this study, production traits showed a high genetic correlation with vegetative variables (Table 2), as with other perennial species, for example, açaí (Farias Neto et al., 2005) and coffee (Freitas et al., 2007; Martinez et al., 2007).

Table 2. Genetic correlations among traits in progenies of Jatropha curcas.
\begin{tabular}{lccccccc}
\hline Traits & NF & NS & PB & SB & SD & PH & PS \\
\hline NB & $0.98^{* *}$ & $0.96^{* *}$ & -0.11 & $0.8^{* *}$ & $0.62^{* *}$ & $0.92^{* *}$ & $-0.53^{*}$ \\
NF & & $0.98^{* *}$ & -0.10 & $0.83^{* *}$ & $0.56^{*}$ & $0.95^{* *}$ & $-0.50^{*}$ \\
NS & & -0.05 & $0.87^{* *}$ & $0.55^{*}$ & $0.90^{* *}$ & -0.37 \\
PB & & & 0.11 & 0.06 & -0.15 & 0.24 \\
SB & & & & $0.55^{*}$ & $0.76^{* *}$ & -0.30 \\
SD & & & & & $0.63^{* *}$ & -0.35 \\
PH & & & & & & $-0.52^{*}$ \\
\hline
\end{tabular}

***Significant at 5 and $1 \%$, respectively. For abbreviations, see legend to Table 1.

It was possible to verify a high positive genetic correlation between $\mathrm{PH}$ and $\mathrm{NB}, \mathrm{NF}$, NS, SD, and PS (Table 2).

The high correlation between PH and production traits was also observed by Rao et al. (2008), who evaluated accessions of J. curcas. Martinez et al. (2007) and Carvalho et al. (2010), who evaluated genotypes of Coffea arabica, and Costa et al. (2008), who evaluated progenies of Hevea brasiliensis, also reported a high correlation between $\mathrm{PH}$ and first production.

Pleiotropism has been identified as the main cause of genetic correlation, while the genetic linkage leads to transient correlations, especially in populations derived from crosses between divergent lineages (Falconer and Mackay, 1996).

The use of correlation coefficients has relevance for quantifying the association between 2 variables. However, when the relationship between a complex trait and its components is analyzed, it is also necessary to assess the direct and indirect effects of each trait on the basic variable (Vencovsky and Barriga, 1992).

The use of path analysis allows a more consistent interpretation of the associations, enabling an evaluation of whether the relationship between 2 variables is the cause and effect or if it is determined by the influence of other variables (Vencovsky and Barriga, 1992; Cruz and Carneiro, 2006).

Multicollinearity problems may yield a singular correlation matrix for the explanatory variables, causing the least square estimates to be unreliable (Cruz and Carneiro, 2006). However, these problems were not found in the matrix for genetic correlation between the variables used in the path analysis (Table 3).

Variable inflation factor values lower than 10, together with reduced levels of condition, high natural values, and condition number less than $100(\mathrm{NB}=44.79)$ (Table 3 ) characterize a weak multicollinearity (Montgomery and Peck, 1981) and do not constitute problems in the decomposition of the correlation coefficients via regression. 
Table 3. Diagnosis of multicollinearity of the correlation matrix of traits: number of bunches, primary branches, secondary branches, stem diameter, and plant height.

\begin{tabular}{lcccc}
\hline Order & Eigen value & Singular value & Condition index & VIF $_{\mathrm{k}}$ \\
\hline 1 & 3.1671 & 1.7796 & 1.0000 & 8.6621 \\
2 & 1.0613 & 1.0302 & 1.7274 & 1.2176 \\
3 & 0.4966 & 0.7047 & 2.5253 & 3.3953 \\
4 & 0.2042 & 0.4519 & 3.9379 & 1.7404 \\
5 & 0.0706 & 0.2658 & 6.6931 & 7.2969 \\
\hline
\end{tabular}

Condition number $=44.79$ (low multicollinearity); determinant of matrix $=0.0241 . \mathrm{VIF}_{\mathrm{k}}=$ variable inflation factor.

The estimates of the coefficients of correlation between NF with NB and PH were similar to the direct effects in terms of magnitude and sign (Table 4) and showed high levels and surpassed the estimate of residual effect, demonstrating that these correlations explain the existing true association, and in this case, that the selection of plants with higher NB and $\mathrm{PH}$ can result in more productive genotypes.

Table 4. Direct (diagonal, in bold) and indirect effects of the growth traits on the number of fruits (NF).

\begin{tabular}{lrccrrr}
\hline Traits & \multicolumn{1}{c}{ NF } & Total \\
\cline { 2 - 5 } & NB & PB & SB & SD & PH \\
\hline NB & $\mathbf{0 . 7 0 9 7}$ & -0.0028 & 0.0678 & -0.0682 & 0.2775 & 0.9841 \\
PB & -0.0808 & $\mathbf{0 . 0 2 4 9}$ & 0.0094 & -0.0061 & -0.0461 & -0.0988 \\
SB & 0.5764 & 0.0028 & $\mathbf{0 . 0 8 3 5}$ & -0.0611 & 0.2282 & 0.8299 \\
SD & 0.4392 & 0.0013 & 0.0463 & $\mathbf{- 0 . 1 1 0 2}$ & 0.580 \\
PH & 0.6557 & -0.0038 & 0.0634 & -0.0689 & $\mathbf{0 . 3 0 0 3}$ & 0.9468 \\
\hline
\end{tabular}

Residual effect $=0.11 ; \mathrm{R}^{2}=0.98$. For abbreviations, see legend to Table 1.

The indirect effect of PH via NB (0.65) also indicates the possibility of selection via $\mathrm{PH}$ as a strategy to obtain genetic gain at an early stage because $\mathrm{PH}$ has a strong effect on the primary component NB and the main trait NF. Moreover, the PH trait has a high selective accuracy (0.81) and may lead to genetic gain for the production traits.

The high correlation between $\mathrm{PH}$ at 2 years and genotypes that are more productive may lead to reducing the risks and costs of seed production of the physic nut and allow the early selection of plants and the attainment of a uniform crop.

Spinelli et al. (2010), who assessed the effect of primary and secondary components on the yield of physic nut oil from the phenotypic correlation matrix, concluded that the canopy volume was the variable with the most influence on oil yield. However, Juhász et al. (2010) estimated low heritability values and selective accuracy for the canopy volume trait; this hinders its use as an auxiliary trait.

The accuracy of indirect selection $\left(\mathrm{h}_{\mathrm{x}} \mathrm{r}_{\mathrm{a}(\mathrm{x}, \mathrm{y}) \text {. }}=0.76\right)$ was higher than the accuracy of direct selection $\left(\mathrm{h}_{\mathrm{y}}=0.69\right)$, demonstrating the efficiency of a correlation between PH and NF.

Successive evaluations will confirm the performance of genetic materials, and the BLUP procedure should be used because it enables greater selection gains and the maximization of selective accuracy. 


\section{Genetic diversity}

In the analyses of genetic diversity, the pseudo- $\mathrm{t}^{2}$ and $-\mathrm{F}$ criteria defined the optimal number of groups as being equal to 4 as well as the likelihood profile, associated with the likelihood ratio test, which showed a greater increase in the likelihood function in the group 4 (52.83) (Figure 1). The logarithmic likelihood function accurately defines the number of groups, resulting in less subjective groupings (Gonçalves et al., 2009).

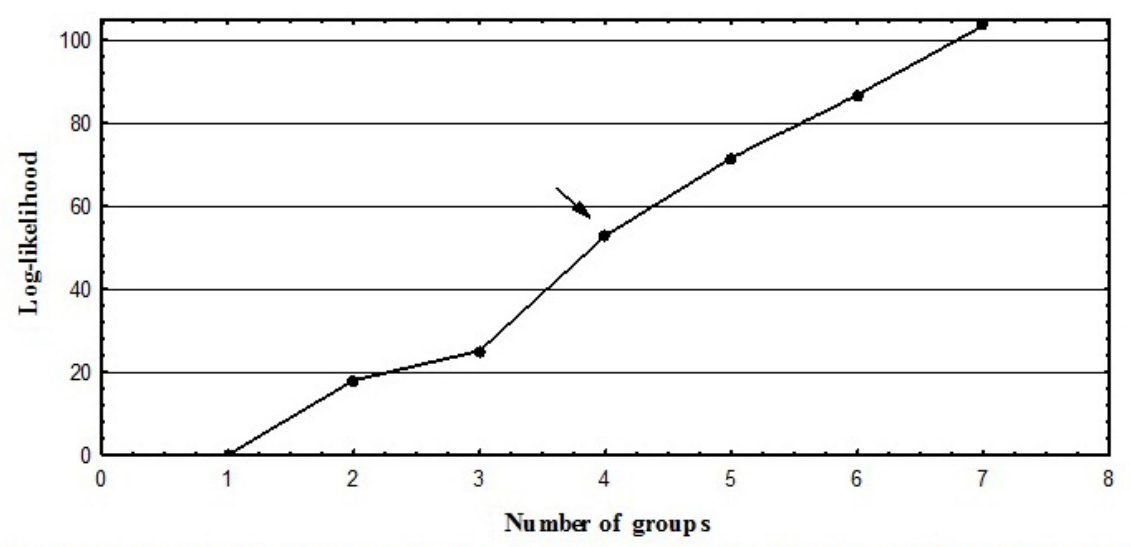

Figure 1. Graph expressing the logarithmic probability function with regard to the optimal number of groups.

The first 2 canonical variables obtained with the Ward-MLM methodology explained $97.51 \%$ of the observed variation, enabling a satisfactory understanding of the genetic variability among accessions evaluated and the relationship between groups and genotypes within groups (Figure 2).

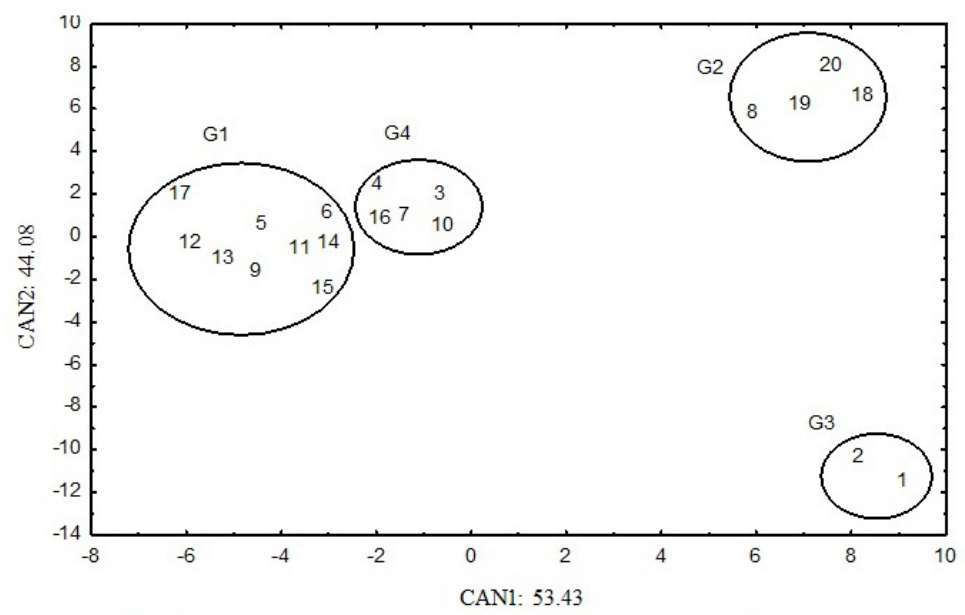

Figure 2. Distribution of the first 2 canonical variables (CAN1 and CAN2) showing the formation of 4 groups (G1G4) by the Ward-modified location model strategy. 
On the basis of the Mahalanobis distance, groups 1 and 4 were the closest, with a distance of 4.44. The highest value was 34.98 for the distance between groups 1 and 2 (Table 5).

Table 5. Separation of groups by the Ward-modified location model strategy, based on Mahalanobis distance.

\begin{tabular}{lcccr}
\hline Groups & G1 & G2 & G3 & G4 \\
\hline G1 & - & 34.98 & 32.91 & 4.44 \\
G2 & 34.98 & - & 30.07 & 16.14 \\
G3 & 32.91 & 30.07 & - & 26.25 \\
G4 & 4.44 & 16.14 & 26.25 & - \\
\hline
\end{tabular}

The genotypes $18,19,20$, and 8 were grouped together and showed the highest mean values for the vegetative and production traits, and the lowest mean values were exhibited by genotypes $17,12,13$, and 9 , which belonged to the same group.

The mean values for all the traits within each group obtained using the Ward-MLM method are presented in Table 6.

Table 6. Average of traits for the 4 groups formed by the Ward-modified location model strategy and the contribution of the traits for the first (CAN1) and second canonical variable (CAN2).

\begin{tabular}{lllllrr}
\hline Traits & G1 & G2 & G3 & G4 & CAN1 $^{\text {a }}$ & CAN2 \\
\hline NB & 0.17 & 1.08 & 0.36 & 0.40 & 0.78 & 0.61 \\
NF & 0.65 & 3.68 & 1.00 & 1.65 & 0.71 & 0.67 \\
NS & 2.01 & 6.47 & 2.54 & 3.72 & 0.68 & -0.66 \\
PB & 3.37 & 3.34 & 3.45 & 3.36 & 0.02 & 0.49 \\
SB & 7.12 & 7.64 & 6.28 & 7.41 & 0.64 & -0.19 \\
SD & 6.30 & 6.44 & 6.52 & 6.35 & 0.92 & -61 \\
PH & 87.90 & 119.00 & 91.80 & 97.00 & 0.67 & -0.30 \\
PS & 92.00 & 87.00 & 90.00 & 90.00 & -0.47 & \\
\hline
\end{tabular}

${ }^{a}$ Correlation among the traits and the first 2 principal components. For abbreviations, see legend to Table 1.

The groups 2 and 4 showed higher mean values for production traits NB, NF, and NS and for the vegetative traits SB and PH. Therefore, hybridization can be performed between the 2 genotype groups in order to explore the effects of heterosis.

The evaluated traits showed high contribution to the genetic divergence on the basis of the correlation with the first 2 canonical variables. The best correlations were the variables $\mathrm{NB}, \mathrm{NF}, \mathrm{NS}$, and $\mathrm{PH}$, demonstrating the importance of these characters to genetic diversity studies (Table 6).

Furthermore, the formation of groups is valuable information in the choice of parents in the breeding programs, since the new hybrid populations to be established must be based on the magnitude of their dissimilarities and potential per se of the parents and the analysis strategy based on the Ward-MLM procedure allowed an appropriate grouping of the accessions of $J$. curcas, which in turn allowed an efficient classification of the evaluated genotypes.

Ward-MLM method allowed the formation of more compact clusters and heterogeneity between the groups; this was also obtained by Padilla et al. (2005) who evaluated local varieties of Brassica rapa subsp rapa L., by Ortiz et al. (2008) who examined accessions of 
maize, by Barbé et al. (2010) who evaluated snap bean, and by Sudré et al. (2010) who evaluated accessions of Capsicum spp.

There is genetic variability in this population, with higher estimates of heritability and accuracy, demonstrating the possibility of obtaining genetic gains for growth and production traits at 24 months after planting. The PH trait can be used for indirect selection in populations of the physic nut in order to obtain superior genotypes.

\section{ACKNOWLEDGMENTS}

Research supported by Fundação de Amparo à Pesquisa do Estado da Bahia (FAPESB).

\section{REFERENCES}

Abreu FB, Resende MDV, Anselmo JL, Saturnino HM, et al. (2009). Variabilidade genética entre acessos de pinhãomanso na fase juvenil. Magistra 21: 36-40. Available at [www.cnpf.embrapa.br/pfb/index.php/pfb/article/ download/83/105]. Accessed March 25, 2012.

Achten WMJ, Verchot L, Franken YJ, Mathijs E, et al. (2008). Jatropha bio-diesel production and use. Biomass Bioenergy 32: 1063-1084. Available at [http://www.sciencedirect.com/science/article/pii/S0961953408000767]. Accessed March 25, 2012.

Achten WMJ, Nielsen LR, Aerts R, Lengkeek AG, et al. (2010). Towards domestication of Jatropha curcas. Biofuels 1: 91-107. Available at [http://www.future-science.com/doi/abs/10.4155/bfs.09.4]. Accessed March 25, 2012.

Barbé TC, Amaral Júnior AT, Gonçalves LSA, Rodrigues R, et al. (2010). Association between advanced generations and genealogy in inbred lines of snap bean by the Ward-Modified Location Model. Euphytica 173: 337-343. Available at [http://link.springer.com/content/pdf/10.1007\%2Fs10681-009-0089-z.pdf]. Accessed March 25, 2012.

Carvalho AM, Mendes ANG, Carvalho GR, Botelho CE, et al. (2010). Correlação entre crescimento e produtividade de cultivares de café em diferentes regiões de Minas Gerais, Brasil. Pesq. Agropec. Bras. 45: 269-275. Available at [www.scielo.br/pdf/pab/v45n3/v45n3a06.pdf]. Accessed March 25, 2012.

Costa RB, Resende MDV, Gonçalves PS, Oliveira LCS, et al. (2008). Seleção simultânea para porte reduzido e alta produção de látex em seringueira. Bragantia 67: 649-654. Available at [www.scielo.br/pdf/brag/v67n3/a13v67n3. pdf]. Accessed March 25, 2012.

Crossa J and Franco J (2004). Statistical methods for classifying genotypes. Euphytica 137: 19-37. Available at [http:// www.springerlink.com/content/gj023731k01n8382/]. Accessed March 25, 2012.

Cruz CD and Carneiro PCS (2006). Modelos Biométricos Aplicados ao Melhoramento Genético. 2nd edn. Universidade Federal de Viçosa, Viçosa.

Fairless D (2007). Biofuel: the little shrub that could - maybe. Nature 449: 652-655. Available at [http://www.nature.com/ news/2007/071010/full/449652a.html]. Accessed March 25, 2012.

Falconer DS and Mackay TFC (1996). Introduction to quantitative genetics. Longman Group Limited, Edinburgh.

Farias Neto JT, Oliveira MSP, Muller AA, Nogueira OL, et al. (2005). Variabilidade genética em progênies jovens de açaizeiro. Cerne 11: 336-341. Available at [http://redalyc.uaemex.mx/pdf/744/74411403.pdf]. Accessed March 25, 2012.

Foidl N, Foidl G, Sanchez M, Mittelbach M, et al. (1996). Jatropha curcas L. as a source for the production of biofuel in Nicaragua. Bioresour. Technol. 58: 77-82. Available at [http://www.sciencedirect.com/science/article/pii/ S0960852496001113]. Accessed March 25, 2012.

Franco J, Crossa J, Villasenõr J, Taba S, et al. (1998). Classifying genetic resources by categorical and continuous variables. Crop Sci. 38: 1688-1696. Available at [https://www.agronomy.org/publications/cs/abstracts/38/6/CS0380061688]. Accessed March 25, 2012.

Freitas RG, Missio RF, Matos FS, Resende MD, et al. (2011). Genetic evaluation of Jatropha curcas: an important oilseed for biodiesel production. Genet. Mol. Res. 10: 1490-1498. Available at [http://www.sumarios.org/sites/default/files/ pdfs/gmr1146.pdf]. Accessed March 25, 2012.

Freitas ZMTS, Oliveira FJ, Carvalho SP, Santos VF, et al. (2007). Avaliação de caracteres quantitativos relacionados com o crescimento vegetativo entre cultivares de café arábica de porte baixo. Bragantia 66: 267-275. Available at [www. scielo.br/pdf/brag/v66n2/10.pdf]. Accessed March 25, 2012. 
Ginwal HS, Phartyal SS, Rawat PS and Srivastava RL (2005). Seed source variation in morphology, germination and seedling growth of Jatropha curcas Linn. in Central India. Silvae Genet. 54: 76-80. Available at [http://www. allgemeineforstundjagdzeitung.de/fileadmin/content/dokument/archiv/silvaegenetica/54_2005/54-2-76.pdf]. Accessed March 25, 2012.

Gonçalves LSA, Rodrigues R, Amaral Júnior AT, Karasawa M, et al. (2009). Heirloom tomato genebank: assessing divergence based on morphological, agronomic and molecular data using Ward-MLM. Genet. Mol. Res. 8: 364-374. Available at [http://www.geneticsmr.com/year2009/vol8-1/pdf/gmr549_abstract.pdf]. Accessed March 25, 2012.

Hallauer AR (2007). History, contribution, and future of quantitative genetics in plants breeding: lessons from maize. Crop Sci. 47: 4-19. Available at [https://www.agronomy.org/publications/cs/articles/47/Supplement_3/S-4]. Accessed March 25, 2012.

Juhász ACP, Morais DLB, Soares BO, Pimenta S, et al. (2010). Parâmetros genéticos e ganho de seleção para populações de pinhão manso (Jatropha curcas). Pesq. Florest. Bras. 30: 25-35. Available at [www.cnpf.embrapa.br/pfb/index. php/pfb/article/download/83/105]. Accessed March 25, 2012.

Laviola BG, Rosado TB, Bering LL, Kobayashi AK, et al. (2010). Genetic parameters and variability in physic nut accessions during early developmental stages. Pesq. Agropec. Bras. 45: 1117-1123. Available at [http://www.scielo. br/scielo.php?pid=S0100-204X2010001000010\&script=sci_arttext]. Accessed March 25, 2012.

Lawrence CJ and Krzanowski WJ (1996). Mixture separation for mixed-mode data. Stat. Comput. 6: 85-92. Available at [http://www.springerlink.com/content/g2364106q815927v/]. Accessed March 25, 2012.

Martinez HEP, Augusto HS, Cruz CD, Pedrosa AW, et al. (2007). Crescimento vegetativo de cultivares de café (Coffea arabica L.) e sua correlação com a produção em espaçamentos adensados. Acta Sci. Agron. 29: 481-489. Available at [http://www.researchgate.net/publication/26604304_Crescimento_vegetativo_de_cultivares_de_caf_\%28Coffea_ arabica_L.\%29_e_sua_correlao_com_a_produo_em_espaamentos_adensados_Vegetative_growth_of the_coffee plant_\%28Coffea_arabica_L.\%29_and_its_correlation_with_the_production_in_narrower_spacing]. March 25, 2012.

Mohammadi SA and Prasanna BM (2003). Analysis of genetic diversity in crop plants - salient statistical tools and considerations. Crop Sci. 43: 1235-1248. Available at [https://www.agronomy.org/publications/cs/ abstracts/43/4/1235]. Accessed March 25, 2012.

Montgomery DC and Peck EA (1981). Introduction to Linear Regression Analyses. John Wiley \& Sons, New York.

Openshaw K (2000). Review of Jatropha curcas: an oil plant of unfulfilled promise. Biomass Bioenergy 19: 1-15. Available at [http://www.sciencedirect.com/science/article/pii/S0961953400000192]. Accessed March 25, 2012.

Ortiz R, Crossa J, Franco J, Sevilla R, et al. (2008). Classification of Peruvian highland maize races using plant traits. Genet. Resour. Crop Evol. 55: 151-162. Available at [http://www.springerlink.com/content/w212458170h543m5/]. Accessed March 25, 2012.

Padilla G, Cartea ME, Rodriguez VM and Ordás A (2005). Genetic diversity in a germplasm collection of Brassica rapa subsp rapa L. from northwestern Spain. Euphytica 145: 171-180. Available at [http://www.springerlink.com/ content/k7030245281226j5/]. Accessed March 25, 2012.

R Development Core Team (2012). R: A Language and Environment for Statistical Computing. R Foundation for Statistical Computing, Vienna.

Rao GR, Korwar GR, Shanker AK and Ramakrishna YS (2008). Genetic associations, variability and diversity in seed characters, growth, reproductive phenology and yield in Jatropha curcas (L.) accessions. Trees 22: 697-709. Available at [http://www.springerlink.com/content/d833r3221q2522g2/]. Accessed March 25, 2012.

Resende MDV (2002). Genética Biométrica e Estatística no Melhoramento de Plantas Perenes. Embrapa Informação Tecnológica, Brasília.

Resende MDV (2007). Selegen-Reml/Blup: Sistema Estatístico e Seleção Genética Computadorizada Via Modelos Lineares Mistos. Embrapa Florestas, Colombo.

SAS Institute Inc. (2007). SAS ${ }^{\circledast}$ 9.1.3 (TS1M3) for Windows Microsoft. SAS Institute Inc., Cary.

Spinelli VM, Rocha RB, Ramalho AR, Marcolan AL, et al. (2010). Componentes primários e secundários do rendimento de óleo de pinhão-manso. Cienc. Rural 40: 1752-1758. Available at [www.scielo.br/pdf/cr/v40n8/a687cr3156.pdf]. Accessed March 25, 2012.

Sudré CP, Gonçalves LSA, Rodrigues R, Amaral Júnior AT, et al. (2010). Genetic variability in domesticated Capsicum spp as assessed by morphological and agronomic data in mixed statistical analysis. Genet. Mol. Res. 9: 283-294. Available at [http://www.geneticsmr.com/year2010/vo19-1/pdf/gmr698.pdf]. Accessed March 25, 2012.

Vencovsky R and Barriga P (1992). Genética Biométrica no Fitomelhoramento. Sociedade Brasileira de Genética, Ribeirão Preto. 